\title{
A modular flow-chamber bioreactor concept as a tool for continuous 2D- and 3D-cell culture
}

\author{
Christiane Goepfert ${ }^{1}$, Grit Blume ${ }^{1}$, Rebecca Faschian ${ }^{1}$, Stefanie Meyer ${ }^{1}$, Cedric Schirmer ${ }^{1}$, Wiebke Müller-Wichards², \\ Jörg Müller ${ }^{2}$, Janine Fischer ${ }^{3}$, Frank Feyerabend ${ }^{3}$, Ralf Pörtner ${ }^{1^{*}}$ \\ From 23rd European Society for Animal Cell Technology (ESACT) Meeting: Better Cells for Better Health \\ Lille, France. 23-26 June 2013
}

\section{Background}

Advanced cell culture models, especially long-term 3D systems, require bioreactors allowing for cultivation under continuous flow conditions. Such culture models are for example tissue engineered implants, 3D cultures for drug testing, in vitro models of cell growth and migration for wound healing studies, cell cultures for biomaterial testing. New challenges in drug testing and biomaterial development arise from regulatory requirements. Animal trials have to be replaced by cell culture assays, preferably by test systems with human material. Standard 2D monolayer cultures are often unsatisfactory and therefore tissue-like 3D cultures are suggested as an alternative. Here the design of a multi-well flow-chamber bioreactor as a tool for manufacturing advanced cell culture models is presented. Advantages of this reactor concept can be seen in constant flow conditions, removal of toxic reaction products, high cell densities, and improved metabolism [1]. The general design of the flow chamber bioreactor (FCBR) can easily be modified for different applications and analytical requirements.

\section{Concept}

The concept of the flow-chamber bioreactor (FCBR) comprises the following features (Figure 1A): Simultaneous cultivation of multiple tissue constructs in special inserts; oxygen supply via surface aeration directly in the chamber; a uniform and thin medium layer which is created by a small barrier at the end of the flow channel to minimize the diffusion distance from the gas phase to the tissue constructs; medium supply from a reservoir bottle in a circulation loop via peristaltic pumps.

\footnotetext{
* Correspondence: poertner@tuhh.de

'Institute of Bioprocess and Biosystems Engineering, Hamburg University of Technology Hamburg, D-21073, Germany

Full list of author information is available at the end of the article
}

Two designs are available: A closed system (single flow channel) with counter current flow of gas and medium for tissue-engineered constructs (Figure 1B), and a 24 well plate-based modular bioreactor (medorex, NörtenHardenberg, Germany) for miniaturized tissue constructs that permits the use of pipetting robots and standard plate readers (Figure 1C).

For the latter one, the design of the 4 channels can be customized for various applications (Table 1). The lid of the plate is connected to tubings for medium recirculation. Medium is supplied via the first well and removed from the last well of each row (Figure 1C). Therefore 4 wells per row are available for construct cultivation.

The closed system is aerated with humidified premixed gas with optional composition. Therefore it can be handled independently from cell culture incubator. The 24 well-based system has to be placed in a humidified incubator for air supply from the incubator atmosphere.

\section{Fields of Application}

For the above mentioned bioreactor designs, four applications are presented in the following.

Example I: The single flow-channel bioreactor (Figure 1 (B)) was designed for the generation of threedimensional cartilage-carrier constructs [2]. The carriers consisting of a bone replacement material were covered with a 1-2 $\mathrm{mm}$ cartilage layer. This reactor was used for long-term cultivation of cartilage-carrierconstructs with improved biochemical parameters (e.g. content of glycosaminoclycan, collagen type II) under constant conditions.

Example II: The 24-well design was successfully applied to several cell culture models. Hepatocytes on porous 3D carriers were cultivated for 1-3 weeks and can be used as a model for drug testing [3]. After prolonged cultivation under continuous medium flow, the 


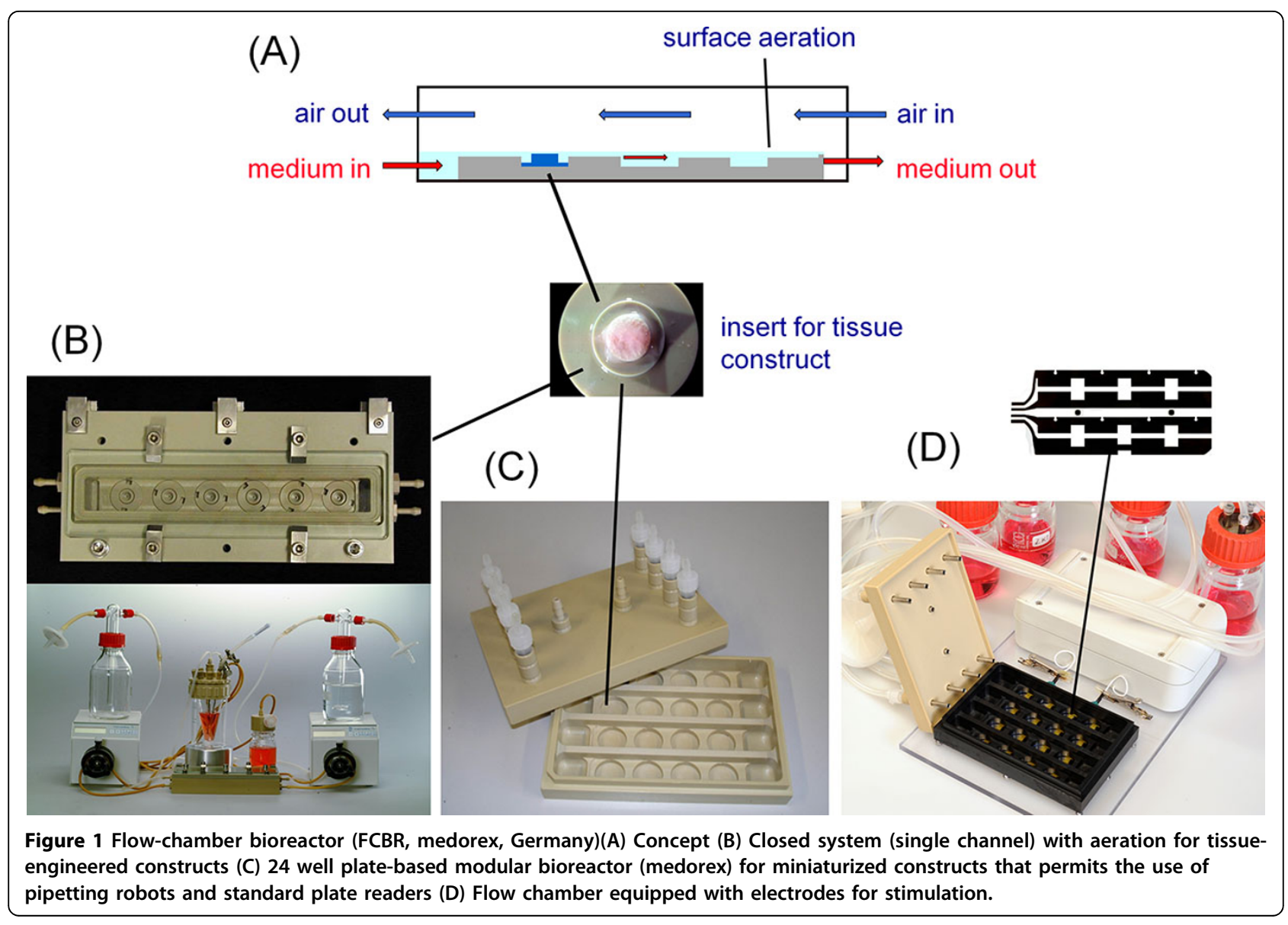

Table 1 Bioreactor configuration and applications

\begin{tabular}{|c|c|c|}
\hline Bioreactor design & Potential applications & Example \\
\hline $\begin{array}{l}\text { I. Single channel, } 6 \text { variable culture inserts for 3D } \\
\text { scaffolds transparent cover plate } \\
\text { active aeration }\end{array}$ & $\begin{array}{l}\text { Long term cultivation of 3D tissue constructs under flow } \\
\text { conditions, } \\
\text { tissue cultivation on implantable biomaterials }\end{array}$ & $\begin{array}{l}\text { Cultivation of } \\
\text { cartilage-carrier } \\
\text { constructs [2] }\end{array}$ \\
\hline $\begin{array}{l}\text { II. } 4 \text { flow channels for perfusion } 24 \text { well plate layout } \\
\text { inserts for } 3 D \text { scaffolds surface aeration gas supply from } \\
\text { humidified incubator }\end{array}$ & $\begin{array}{l}\text { Simultaneous cultivation of four 3D constructs per channel, } 4 \\
\text { channels available, separate functional tests can be carried out } \\
\text { on single constructs }\end{array}$ & $\begin{array}{l}\text { 3D cultures of liver } \\
\text { cells [3], biomaterial } \\
\text { testing }\end{array}$ \\
\hline $\begin{array}{l}\text { III. As (II), transparent bottom plate for microscopy flow } \\
\text { channels instead of separate wells }\end{array}$ & $\begin{array}{l}\text { Cultivation of shear-responsive cells, integration of biomaterials } \\
\text { possible (e.g. a collagen membrane) }\end{array}$ & $\begin{array}{l}\text { Cultivation of sweat- } \\
\text { gland associated cells } \\
\text { (current) }\end{array}$ \\
\hline $\begin{array}{l}\text { IV. As (II) plus integrated of electrodes for electrical } \\
\text { stimulation and impedance measurement }\end{array}$ & $\begin{array}{l}\text { Electrical stimulation of cell growth and orientation, impedance } \\
\text { measurement of cell viability }\end{array}$ & $\begin{array}{l}\text { Orientation of mitotic } \\
\text { axis [5] }\end{array}$ \\
\hline
\end{tabular}

constructs are separated from each other for measurements in static operation mode to conduct viability and activity assays similar to procedures done in a standard multi well plate. Viability testing using Resazurin was performed repeatedly during cultivation. Furthermore, the EROD-assay for liver-specific cytochrome P450 activity was carried out at varying time points. Application for the resorption studies on magnesium implants is currently investigated by Prof. Willumeit, Dr. Feyerabend, HZ Geesthacht.
Example III: A third layout of the MWFB was realized with four parallel flow channels instead of the separate wells. There is also the possibility to carry out material tests for cell expansion on specific materials (e. g. polymer films, collagen membranes, different coatings etc.).

Example IV: Proliferation and migration of fibroblasts on collagen coated polymer foils integrated into the bioreactor was carried out using design IV (Figure $1 \mathrm{C}$ ). Electrical stimulation of NIH-3T3 fibroblasts resulted in 
the orientation of the cell cleavage plane perpendicular to the electric field vector. The electrodes were inserted into the chamber on a polymer foil clamped between the base plate and the 24 well plate equivalent top frame. The polymer foil can be removed and processed after the assays for staining and microscopic evaluation of the stimulated cells. The bottom plate was realized in a transparent material for microscopy. The frequency of unipolar pulses can be varied between $16 \mathrm{~Hz}$ and $2 \mathrm{kHz}$, the voltage between 0 up to $600 \mathrm{mV}$ and stimulation pulse to pause ratios between 1:1, 1:10 and 1:100

\section{Conclusions}

The flow chamber concept and its different modifications can be applied as an easily applicable and versatile tool for advanced cell culture models. The 24 well design is suitable for application in a standard cell culture lab without special bioreactor equipment: For medium supply, standard peristaltic pumps with 4 channels can be used. The bottom plate can be handled in a similar way as 24 well plates allowing for adaptation of standard assays to long-term 3D cultures, electrically stimulated cells, or primary cells cultivated on membranes consisting of various biomaterials.

\section{Authors' details}

${ }^{1}$ Institute of Bioprocess and Biosystems Engineering, Hamburg University of Technology Hamburg, D-21073, Germany. ${ }^{2}$ Institute of Micro System Technology, Hamburg University of Technology, Hamburg, D-21073, Germany. ${ }^{3}$ Department of Structural Research on Macromolecules, Institute of Materials Research, Helmholtz-Zentrum Geesthacht, Geesthacht, D-21502, Germany.

Published: 4 December 2013

\section{References}

1. Pörtner R, Goepfert C, Wiegandt K, Janssen R, llinich E, Paetzhold H, Eisenbarth E, Morlock M: Technical Strategies to Improve Tissue Engineering of Cartilage Carrier Constructs - A Case Study. Adv Biochem Eng/Biotechnol 2009, 112:145-182.

2. Nagel-Heyer S, Goepfert Ch, Adamietz P, Meenen NM, Petersen JP, Pörtner R: Flow-chamber bioreactor culture for generation of threedimensional cartilage-carrier-constructs. Bioproc Biosyst Eng 2005, 27:273-280.

3. Goepfert C, Scheurer W, Rohn S, Rathjen B, Meyer S, Dittmann A, Wiegandt $K$, Janßen R, Pörtner R: 3D-Bioreactor culture of human hepatoma cell line HepG2 as a promising tool for in vitro substance testing. BMC Proceedings 2011, 5:P61.

4. Starbird R, Krautschneider W, Blume G, Bauhofer W: In Vitro Biocompatibility Study and Electrical Properties of the PEDOT, PEDOT Collagen-Coat, PEDOT Nanotubes and PEDOT Aerogels for Neural Electrodes. Biomedical Engineering (BioMed 2013) Proceedings Innsbruck, Austria; 2013.

5. Saß W, Blume G, Faschian R, Goepfert C, Müller J: Wachstumsstimulation von Fibroblasten mit Platin/PEDOT Elektroden auf hochflexiblen Folien. In Mikrosystemtechnik Kongress VDE VERLAG BerlinBMBF; VDE; GMM; VDI/ VDE-IT 2012, ISBN 978-3-8007-3367-5.

doi:10.1186/1753-6561-7-S6-P87

Cite this article as: Goepfert et al: A modular flow-chamber bioreactor concept as a tool for continuous 2D- and 3D-cell culture. BMC Proceedings 2013 7(Suppl 6):P87.

\section{Submit your next manuscript to BioMed Central and take full advantage of:}

- Convenient online submission

- Thorough peer review

- No space constraints or color figure charges

- Immediate publication on acceptance

- Inclusion in PubMed, CAS, Scopus and Google Scholar

- Research which is freely available for redistribution 